\title{
Cordonnier Viral Complication
}

National Cancer Institute

\section{Source}

National Cancer Institute. Cordonnier Viral Complication. NCI Thesaurus. Code C138290.

Any virally-focused infection complications occurring in allogeneic stem cell transplant recipients. 